\title{
A Holistic-Integrative Approach to Early Childhood Education Quality Improvement - The Case of Pemalang Regency
}

\author{
Lita Latiana ${ }^{1}$, Dyah Retno Fitri Utami ${ }^{2}$ \\ \{lita.unnes@gmail.com ${ }^{1}$, dyahretnouf@gmail.com² \\ Graduate School, Universitas Negeri Semarang, \\ Semarang, Indonesia ${ }^{1,2}$
}

\begin{abstract}
Gross Enrollment Ratio of ECE in Pemalang Regency shows $68.38 \%$ and there are 523 early childhood institution that haven't all conducted HI services. This study focuses on improving the quality management of ECE HI directed to describe and analyze: 1) the management implementation of ECE HI, 2) the collaboration between government institutions and organizations related to ECE providers in producing quality education. This is a descriptive research with subjects are teachers, headmaster, ECE supervisor and related elements in applying ECE HI. The results showed that the management of ECE HI in Pemalang Regency wasn't optimal. This happened because the government's carrying capacity is still low and comprehension of some educators and health cadres regarding HI services that haven't been maximized. Recommendations that the quality of ECE HI services can be carried out properly need to be developed in a system of integrated quality management.
\end{abstract}

Keywords: early childhood education, holistic integrative, management quality.

\section{Introduction}

Education is a right of citizen that must be fulfilled, including education for early childhood. Early Childhood Education (ECE) is the main and most important investment in the preparation of quality human resources. But, a majority of the world's youngest children still lack access to quality Early Childhood Development (ECD) services ${ }^{[1]}$. The implementation of Early Childhood Education through Holistic and Integrative services (ECE $\mathrm{HI})$ is an effort to optimize all potentials of children (0-6 years) in accordance with the rights and needs of children. Education for early childhood must be able to provide good and comprehensive services. The concept of education in ECE HI can be understood as an integrated, systematic, and harmonious system that involves all aspects that influence to the process of child development ${ }^{[2]}$. Holistic stimulation services include education, health, nutrition, care, nurturing, protection and welfare into the policy of early childhood development by involving relevant parties of government agencies, community organizations, professional organizations, community leaders, and parents ${ }^{[3,4]}$.

ECE HI emphasizes the integration of all components that support the success of child development requires the manager to establish good relationships with all these components through partnerships or cooperation with various parties involved in the development of the ECE HI program. Community participation in ECE HI must be inherently connected to each 
other for stable polity and good governance, as well as expansion of educational, beside that understanding the governance of systems is important for producing the best ECE HI ${ }^{[5,6]}$.

This research was conducted at Pemalang Regency, Central Java, Indonesia. Administratively, Pemalang Regency is divided into 14 sub-districts, and there are 222 villages. At present, in the region, there are 15 institutions which are the pilot projects of ECE $\mathrm{HI}$ as the program of UNICEF and 3 institutions from the communities in 14 villages in seven sub-districts. Based on the APK data for the ECE of Pemalang Regency in 2013-2017, total of population aged 0-6 years was $24.76 \%$ with the details of $12.74 \%$ of men and $12.02 \%$ of women of the total population. The people with potential ages to participate in early childhood education were $4.50 \%$ for men and $4.36 \%$ for women, and not all of them attended early childhood education. This shows that there are still many school-age children who do not attend ECE either non-formal or formal ECE.

In addition to the low participation of children in attending ECE, there are several other obstacles in the implementation of ECE HI in Pemalang Regency so that it has not run optimally. The main obstacle faced is on human resources with low competence and qualifications of the health cadres and educators. Actually, effective ECE depends on the competence of personnel and qualified teachers, besides that interaction of institutions determines whether a negative or positive effect on child development takes place ${ }^{[7]}$. Therefore, it needs more empowerment to support the quality implementation of ECE $\mathrm{HI}{ }^{[8,9]}$. Quality of ECE has qualified educators with the qualifications which are in accordance with the requirements as ECE teachers (skilled, creative, understanding child development, possessing modest personalities and behaviors in order to be role models for students) and have quality services with learning qualifications that contain moral, religion, and local contents $^{[10,11]}$.

The low level of the ECE HI services available in Pemalang Regency is due to the lack of institutions that provide early childhood education services which are inversely proportional to the number of children supposed to obtain these services. Generally the obstacles faced in the implementation of ECE HI include facilities and infrastructure which have not been fulfilled. Besides, the government's carrying capacity is still low, and the understanding of some educators regarding integrative holistic services have not been maximized and the lack of references that can be used as references in implementation ${ }^{[12]}$. For integrated ECE services, understanding governance systems is important in order to ensure they are well planned, implemented, and coordinated ${ }^{[13]}$.

The implementation program of ECE HI has become a government policy carried out through the Presidential Regulation Number 60 of 2013 concerning ECE HI, but not all ECE institutions have holistic integrative services. Many early childhoods have not obtained maximum growth and development services. The efforts that can be made in overcoming these problems are conducting research in the realm of early childhood that develops the needs of child development systematically, and involves all early childhood development actors. It is expected that the fulfillment of the optimal right of child development can be fulfilled holistically through the implementation of integrated ECE. The aims of the study were to describe and analyze: 1) the management implementation of ECE HI, and 2) the collaboration between government institutions and organizations related to ECE providers in producing quality education. Through this research, it can describe the management of ECE HI in Pemalang Regency and analyze cooperation of related institutions so that it can be used as a reference in the efforts to strengthen the quality of ECE HI services. 


\section{Methods}

This study was intended to explore the management implementation of ECE HI and collaboration among the institutions related to HI services in the ECE of Pemalang Regency that used descriptive research. The study involved teachers, principals, and ECE supervisors and related elements. The data collection techniques in this study was used questionnaires and interviews. The data obtained from questionnaires about management of ECE HI was processed using simple statistics, whereas data obtained from interviews was analysis using the Miles \& Huberman analysis model. After the interview data is obtained, the data is reduced, presented, and conclused, so that it can answer the problems that were present.

\section{Results and Discussion}

The findings of this study describe the management of ECE HI services in Pemalang Regency and the collaboration of government and organizational institutions related to ECE HI providers.

\section{a. Management of ECE HI in Pemalang Regency}

The implementation of ECE HI in Pemalang Regency consists of the services that include the aspects of health, education, protection, care, and welfare. The implementation of health service program is presented through the following table:

Table 1. Health Services of ECE HI in Pemalang Regency

\begin{tabular}{lcc}
\hline \multicolumn{1}{c}{ Service Programs } & Number & Percentage (\%) \\
\hline Protection & 3 & 16.7 \\
Health and Nutrition & 15 & 83.3 \\
DDTK & 18 & 100 \\
Stimulation & 8 & 44.4 \\
Caring & 4 & 22.2 \\
\hline
\end{tabular}

The HI ECE service program in Pemalang Regency shows that the Early Childhood Development Detection Service (DDTK) is a type of service that has been used by all HI ECE institutions in Pemalang with a total of 18 schools with a percentage of $100 \%$. In health and nutrition services, 15 schools had implemented them with a percentage of $83.3 \%$; stimulation services at $44.4 \%$ with a total of eight schools; and protection and care services were the services that hadn't been fully implemented with a percentage of $16.7 \%$ and $22.2 \%$ respectively. 
The ECE HI in education services is shown in the following table

Table 2. Educational Services of ECE HI in Pemalang Regency

\begin{tabular}{llcc}
\hline \multicolumn{2}{c}{ Curriculum } & Number & Percentage (\%) \\
\hline Curriculum & K 2013 & 15 & 83.3 \\
Model & & & \\
& Sentra & 12 & 66.7 \\
Time & Area & 3 & 16.7 \\
& A half & 15 & 83.3 \\
Prota Promes & day & & \\
RPPM/ RPPH & & 10 & 55.6 \\
Teaching Materials & 13 & 72.2 \\
Learning Media & 13 & 72.2 \\
Assessment Tool & 13 & 72.2 \\
\hline
\end{tabular}

The most widely used curriculum in the school institutions was from the the K 2013 curriculum $(83.3 \%)$ and the rest did not mention the curriculum. The learning activity models used in the institutions mostly used the model of Sentra (66.7\%) and Area (16.7\%). Fifteen institutions conducted a half-day activity $(83.3 \%)$, and the rest did not mention the duration of the activity. The curriculum supporting documents such as Prota/ Promes, RKM/ RKH, teaching materials, learning media, and assessment tools were not entirely owned by the institutions with the percentage of each document of $55.6 \%, 72.2 \%, 72.2 \%, 72.2 \%$, and $66.7 \%$ respectively. Then the income in the ECE HI institution is presented through the following table 3.

Table 3. Financial Sources of ECE HI in Pemalang Regency

\begin{tabular}{lcc}
\hline Financial Sources & Total & Percentage $(\boldsymbol{\%})$ \\
\hline Center & 3 & 16.7 \\
Province & 3 & 16.7 \\
Regency & 7 & 38.9 \\
Village & 3 & 16.7 \\
Parents & 7 & 38.9 \\
Donors & 6 & 33.3 \\
\hline
\end{tabular}

The financial sources obtained in the institutions varied with the biggest financial source from the regency government and parents with a percentage of $38.9 \%$. Then, the financial income from donors reached $33.3 \%$, and the central, provincial and village governments provided a financial supply of $16.7 \%$.

Related to monitoring and evaluation activities in an effort to guarantee the quality of institutions carried out by related parties and displayed through the following table 
Table 4. Monitoring and Evaluation of ECE HI in Pemalang Regency

\begin{tabular}{llcc}
\hline \multicolumn{2}{c}{ Monev } & Total & Percentage (\%) \\
\hline $\begin{array}{l}\text { The Making of Monthly } \\
\text { Report }\end{array}$ & 3 & 16.7 \\
Officers & Sub-District & 3 & \\
& City/ Regency & 3 & 16.7 \\
& Province & 3 & 16.7 \\
Technique & Questionnaire & 4 & 16.7 \\
& Direct & - & 22.2 \\
Feedback & & 3 & - \\
Follow-Up & & 3 & 16.7 \\
KKG & & 10 & 16.7 \\
\hline
\end{tabular}

Preparation of reports was only carried out by three institutions $(16.7 \%)$ with monthly frequency, while the other institutions did not make monthly reports. Monitoring and evaluation activities conducted by involving the officers from Sub-District, City/ Regency, and Province were held by three officers (16.7\%). Monev activities were carried out by the officers using questionnaire techniques by four institutions $(22.2 \%)$, and the rest did not mention the techniques used by the officers to take the data. Feedback and follow-up from the monitoring and evaluation of each activity were only carried out in three institutions (16.7\%). The implementation of the KKG in the institution was carried out by 10 institutions (55.6\%).

Management in education is a process of cooperation carried out by a group of people to achieve a common goal. In order to develop the essential needs of early childhood through ECE HI services, several programs provided in one ECE service include health, nutrition, nurturing, protection, and educational stimuli services which are simultaneously interrelated and systematically arranged with the aim of developing children's potential optimally. Based on the research results, the efforts in the quality management of ECE HI in Pemalang Regency can be carried out in accordance with regulation of the national education minister number 137 of 2014 by having qualified and competent educators in their fields, running high quality services and in accordance with the needs of students, applying quality management by paying attention to management from various aspects, have systematically arranged regulations to create order, and having good coordination and communication with various parties in order to produce quality education.

However, in reality, currently the implementation of ECE HI in Pemalang Regency hasn't run optimally due to the presence of several obstacles faced in the implementation of ECE HI. From health aspect, the obstacles faced in Pemalang Regency are high maternal mortality, infant mortality and under-five mortality, stunting toddlers, early detection activities of the development of children under five which have not run optimally, and the low competence level of health cadres.

In educational aspect, the obstacles were low competence and qualifications of ECE educators, inadequate availability of representative ECE facilities and infrastructures, low welfare of ECE educators and education staffs, low public awareness on the importance of ECE, and the behavior and culture of early childhood which is not in accordance with the standards of child development achievement level. In other hand, in the aspects of protection, care and welfare, there is still a high rate of violence against children, low level of care for children with special needs, low child welfare, children with no population documents. 


\section{b. Collaboration Between Government Institutions and the Organizations Related to ECE HI Providers}

Implementation of ECE HI is an integrated effort of stakeholders, both government and non-government, which aims to improve overall early childhood development system in Pemalang Regency. The successful implementation of ECE HI strategy for all children without exception is inseparable from strong commitment of all parties, community, and businesses. In addition, the success of this effort is also very dependent on the agreement between Regency and Sub-District governments regarding the urgency of optimizing ECE HI as the most basic element of national development.

The collaboration in the implementation of ECE HI in Pemalang Regency involves various government institutions and related organizations with their own duties and roles incorporated in the ECE HI task force. The task force formed is based on Presidential Regulation number 60 of 2013 concerning Integrative Holistic of Early Childhood Development and the Regulation of the People's Coordinating Minister Number 6 of 2014 concerning the ECE HI Task Force. In addition, the task force has membership consisting of various government institutions and relevant organizations such as (1) Community Empowerment and Village Government Office of Pemalang Regency; (2) Head of the Health Office of Pemalang Regency; (3) Head of the Population and Civil Registration Service of Pemalang Regency; (4) Head of the Social Service, Population Control, Family Planning, Women's Empowerment and Child Protection in Pemalang Regency; (5) Head of the Communication and Information Office of Pemalang Regency; (6) Head of Legal Division of the Regional Secretariat of Pemalang Regency; (7) Head of the Ministry of Religion of Pemalang Regency; (8) Head of the Central Bureau of Statistics of Pemalang Regency; (9) Chairperson of the Education Council of Pemalang Regency; (10) Chairperson of the PKK Driving Team in Pemalang Regency.

Indeed, in implementing ECE HI in Pemalang district, it has involved various related parties, but in reality this has not been able to produce maximum $\mathrm{HI}$ services so that it needs to develop a system of integrated quality management.

\section{Conclusion}

The ECE HI service that has been implemented by 18 institutions in Pemalang Regency based on its practice has been able to be implemented even though it has not been implemented optimally. This happens because the government's carrying capacity is still low. In addition, the understanding of some educators regarding integrative holistic services has not been maximized and the lack of references that can be used as the references in the implementation of ECE HI so that more empowerment is needed to support the implementation of quality ECE HI. 


\section{References}

[1] UNICEF.: Inequities in Early Childhood Development: What the Data Say. Evidence from the Multiple Indicator Cluster Surveys. Pp.1-16 (2012).

[2] Farida.: Penyelenggaraan Program PAUD HI Melalui Kemitraan dalam Meningkatkan Aspek Perkembangan Kognitif Anak Usia Dini. Vol 1. Pedagogia Jurnal Ilmu Pendidikan (2015).

[3] Adiarti, W., et.al.: The Implementation of Holistic Integrative Services in Early Childhood Education (ECE): Perspective on 2013 ECE Curriculum in Indonesian Preschool, Vol.28, pp.292-300 (2017).

[4] Vargas-Baron, E.: Building and Strengthening National Systems for ECD In Handbook of ECD Research and Its Impact on Global Policy. pp.443-466 (2013).

[5] Abbas, I.M.: A Community Participation in Education: Challenges and Prospects in Nigeria's Democracy. Vol.8, pp.1-11. Ahmadu Bello University (2012).

[6] Britto, et.al.: Strengthening systems for integrated early childhood development services: a crossnational analysis of governance. Vol.1, pp.245-255. New York Academy of Sciences (2014).

[7] Podmore \& Hendricks.: Aspects of Quality in Early Childhood Education. New Zealand Council for Educational Research. (2000).

[8] Yulianto, et.al.: Analisis Pembelajaran Holistik Integratif pada Anak di TK Negeri Pembina Kabupaten Kediri. Vol. 2, pp.227-294. Jurnal Pendidikan Usia Dini (2016).

[9] Hajati.: Pelaksanaan Pendidikan Holistik Integratif dalam Pelayanan Kebutuhan Dasar Anak Usia Dini di Sulawesi Barat.Vol.1, pp.17-24. Indonesian Journal of Educational Sciene (2018).

[10] Waluyo, et.al.: Pendidikan Anak Usia Dini (PAUD) Berkualitas dalam Perspektif Guru dan Orangtua: Studi Informasi Dasar Bagi Pengembangan Standar Kualitas PAUD. DP2M. DIKTI (2013).

[11] Yuniarto \& Khasanah.: Integrative Holistic Development Program in School Integral Hidayatullah Yaa Bunayya Batang. Vol.1, pp.41-48. Indonesian Journal Of Early Childhood Education Studies (2014).

[12] Hidayati.: Pendidikan Holistik Integratif di Raudlatul Athfal (RA). Vol. 15, pp. 241-262. Jurnal Penelitian Pendidikan Agama dan Keagamaan (2017).

[13] Britto, P.R., P.L. Engle \& C.M. Super.: Handbook of Early Childhood Development Research and Its Impact on Global Policy. New York: Oxford (2013). 